\title{
Penegakan Hukum terhadap Pelaku Tindak Pidana Pertambangan Minyak Tanpa Izin (Illegal Drilling) di Wilayah Hukum Kabupaten Batanghari
}

\author{
Muhammad Badri ${ }^{1}$, Eka Pitri ${ }^{2}$ \\ Fakultas Hukum Universitas Batanghari \\ Correspondence email: muhammadbadri1972@gmail.com, Princesseka2018@gmail.com
}

\begin{abstract}
Abstrak. Minyak dan gas bumi merupakan sumber daya alam yang dipegang dan dikuasai oleh Negara yang harus dioptimalkan dengan semaksimal mungkin karena mempunyai peranan yang sangat penting dalam perekonomian nasional, yang muara dari kegiatan tersebut terciptanya kesejahteraan sosial bagi seluruh masyarakat Indonesia. Guna mencapai kesejahteraan tersebut, ditetapkannya Undang-undang Nomor 22 Tahun 2001 Tentang Minyak dan Gas Bumi, yang mana undang-undang ini memberikan landasan hukum bagi pembangunan dan pembaharuan hukum pada kegiatan usaha minyak dan gas. Adapun tujuan dari penelitian ini yaitu ingin mengetahui penegakan hukum terhadap tindak pidana pertambangan minyak tanpa izin di wilayah hukum Kabupaten Batanghari, kendala yang dihadapi serta upaya yang dilakukan untuk mengatasi kendala yang dihdapai. Penelitian ini merupakan penelitian deskriptif analitis dengan pendekatan yuridis empiris. Penentuan sampel dilakukan dengan menggunakan teknik Purposive Sampling dan pengumpulan data dilakukan melalui wawancara serta analisis data dilakukan secara kualitatif. Penegakan hukum yang dilakukan yaitu melakukan tindakan represif, penindakan serta penahanan. Kendala yang dihadapi yaitu rendahnya kesadaran, partisipasi dan informasi dari masyarakat dan kendala lain yaitu kebocoran informasi. Upaya yang dilakukan yaitu meningkatkan kesadaran dan partisipasi serta memaksimalkan peran masyarakat.
\end{abstract}

Kata Kunci : penegakam, pelaku, pertambangan,minyak

\begin{abstract}
Oil and gas are natural resources that are held and controlled by the State which must be optimized to the maximum extent possible because they have a very important role in the national economy, the estuary of which is the creation of social welfare for all Indonesian people. In order to achieve this welfare, Law Number 22 of 2001 concerning Oil and Gas is enacted, which provides a legal basis for development and legal reform in oil and gas business activities.The purpose of this study is to find out law enforcement against the crime of oil mining without a permit in the jurisdiction of Batanghari Regency, the obstacles faced and the efforts made to overcome the obstacles encountered. This research is a descriptive analytical research with an empirical juridical approach. Determination of the sample was carried out using purposive sampling technique and data collection was carried out through interviews and qualitative data analysis was carried out. Law enforcement is carried out by carrying out repressive actions, taking action and detention. Constraints faced are low awareness, participation and information from the community and another obstacle is information leakage. Efforts are being made to increase awareness and participation and maximize the role of the community.
\end{abstract}

Keywords: enforcement, perpetrators, mining, oil

\section{PENDAHULUAN}

Pembangunan di Indonesia meliputi seluruh bidang, dan salah satunya adalah pembangunan dalam bidang hukum, yang mana pembangunan dalam bidang hukum mempunyai istilah yaitu pembaharuan hukum atau law reform.Pembangunan hukum atau pembaharuan hukum yang mana merupakan bagian dari pembangunan nasional, haruslah melakukan pembaharuan hukum secara menyeluruh baik itu hukum pidana, perdata, hukum administrasi juga termasuk kedalamnya yaitu hukum formil dan materil.

Dalam kerangka pembangunan hukum yang merupakan pembangunan nasional tadi, maka moral, jiwa, dan hakikat serta perkembangan zaman yang melandasinya harus dipahami dan dihayati. Penghayatan dalam rangka pembangunan nasional tersebut tidak boleh dilepaskan dari pada pancasila dan undang-undang dasar 195. Konsekuensi dari pembangunan nasional tersebut, pembangunan hukum harus bisa menyesuaikan perubahan dan dinamika yang terjadi di dalam kehidupan masyarakat. Hukum bisa menjadi alat pengendali dalam kehidupan masyarakat dan juga bisa menjadi alat perubahan sosial dalam masyarakat (tool of spencing). ${ }^{3}$

Usaha yang dilakukan untuk pembaharuan hukum pidana sampai sekarang terus dilakukan. Pembaruan hukum tersebut pada dasarnya untuk mengganti dasar hukum pidana yang lama dengan hukum pidana yang baru yang sesuai dengan kondisi dan sifat masyarakat indonesia. Wetboek van Strafrecht voor Nederlandsch Indie merupakan hukum pidana warisan kolonial yang mulai berlaku pada tahun $1915 .{ }^{4}$

\footnotetext{
1 Dosen Fakultas Hukum Universitas Batanghari

2 Mahasiswa Fakultas Hukum Universitas Batanghari

${ }^{3}$ Satjipto Rahardjo, Sisi-sisi Lain dari Hukum di Indonesia, Penerbit Kompas, Jakarta, 2006, hal. 52

${ }^{4}$ Muladi, Lembaga Pidana Bersyarat, cetakan ketiga, Alumni, Bandung, 2005, hal 4.
} 
Pembaharuan dan pembangunan hukum pidana terus diupayakan dengan arah yang jelas dan terpadu. Karena sangat dibutuhkan kodifikasi serta unifikasi dalam susunan perundang-undangan yang baru. Instrumen hukum yang bentuknya perundang-undangan sangat dibutuhkan dengan menyesuaikan nilai yang ada di dalam masyarakat dengan memberikan penyuluhan dan kesadaran hukum di dalam diri masyarakat sehingga hukum itu hidup di dalam jiwa masyarakat. ${ }^{5}$

Barda Nawawi Arief mengatakan bahwa pembaruan hukum yang dilakukan tidak sekedar mengenai subtansi tetapi juga mengenai nilai dan norma yang ada dalam hukum tersebut. Barda Nawawi mengatakan bahwa proses pembaruan hukum pidana pada dasarnya menyangkut reorientasi dan reformasi hukum. Pembaruan tersebut harus disesuaikan dengan kultur budaya masyarakat indonesia baik sosio politik, filosofik maupun kulturalnya. ${ }^{6}$

Terhadap masalah kemanusian dan masalah kemasyarakatan sudah banyak usaha dan upaya penanggulangan yang dilakukan berbagai cara, salah satu usaha yang dilakukan yaitu penegakan hukum melalui hukum pidana sebagai salah satu penegakan hukum. Akan tetapi hal ini masih menjadi hal yang diperdebat dan didiskusikan karena efek yang dihasilkan masih belum maksimal. Menurut Herbert L, Packer, yang di kutip oleh Teguh Prasetyo, merupakan dimensi yang sangat penting pada penggunaan pidana kepada orang yang melakukan pelanggaran dengan berbuat tindakan yang anti sosial. ${ }^{7}$

Perubahan dan perkembangan masyarakat disebabkan salah satunya karena perkembangan dunia yang kita kenal dengan nama globalisasi, industrisasi dan modernisasi. Perubahan tersebut menyebabkan perubahan dalam tatanan sosial masyarakat. Pertambangan minyak tidak luput terkena dampak akibat perubahan industrisasi yang terjadi. Oleh karenanya kekayaan minyak yang dimiliki oleh suatu negara harus dikuasai negara itu sendiri sehingga dapat dimanfaatkan semaksimal mungkin untuk kehidupan masyarakatnya. Selain itu kekayaan minyak merupakan kekayaan yang dapat membantu dalam perekonomian nasional yang mana muara dari kegiatan tersebut terciptanya kesejahteraan sosial bagi seluruh masyarakat Indonesia. Guna mencapai kesejahteraan tersebut, ditetapkannya Undang-undang Nomor 22 Tahun 2001 Tentang Minyak dan Gas Bumi, yang mana undang-undang ini memberikan landasan hukum bagi pembangunan dan pembaharuan hukum pada kegiatan usaha minyak dan gas.

Minyak dan gas bumi sebagaimana yang dijelaskan dalam Undang-undang Nomor 22 Tahun 2001 yaitu sumber daya alam strategis dan menjadi kekayaan tambang nasional dan terhadap kekayaan tambang tersebut diawasi oleh negara. Konsekuensi logisnya bahwa kekayaan tambang tersebut dikuasai oleh negara dan dijalankan atau dimanfaatkan oleh negara sebagai pemegang kekuasaan untuk kepentingan nasional. Kekayaan tambang tersebut menjadi salah satu sumber kekayaan dan pembiayaan, energi dan bahan bakar.

Peraturan Menteri Energi Sumber Daya Mineral (Permen) Nomor 1 Tahun 2008 tentang Pengusahaan Pertambangan Minyak Bumi pada sumur tua sebagai turunan dari Undang-Undang Nomor 22 Tahun 2001 tentang MIGAS, dalam melakukan pengelolaan pertambangan minyak pada sumur tua atau sumur yang masih mengandung minyak diatur dalam pasal 2 Peraturan Menteri Energi Sumber Daya Mineral Nomor 1 tahun 2008 yang berbunyi "Bahwa diperlukan kerjasama antara pemerintah dengan kontraktor guna pengelolaan pertambangan sumur tua yang masih mengandung minyak dengan persetujuan Menteri”.

Berdasarkan pasal 2 Peraturan Menteri Energi Sumber Daya Mineral Nomor 1 tahun 2008 tersebut diatas tersebut apabila tidak melakukan kerja sama antara masyarakat dengan kontraktor maka pertambangan minyak tersebut merupakan pertambangan tanpa izin (illegal drilling).

Sumber daya alam yang dimiliki Indonesia khususnya bahan tambang yang lebih dari pada Negara-negara lain, maka untuk itu dibutuhkan suatu regulasi atau pengaturan yang ketat guna memberikan perlindungan dalam pemanfaatan bahan tambang tersebut. Sumber daya alam ini merupakan sumber daya alam yang tidak dapat diperbaharui dan jika digunakan terus menerus akan mengalami kehabisan sehingga dibutuhkan regulasi atau aturan yang dapat mengatur penggunaan sumber daya alam tersebut sehingga didapatkan penggunaan yang efisien dan efektif. Sumber daya alam yang tidak dapat diperbaharui merupakan sumber daya alam yang tersedia dari alam dengan proses yang sangat panjang dan untuk pembaharuannya dibutuhkan waktu yang sangat penjang pula. Penggunaan yang terus menerus akan menyebabkan sumber daya alam tersebur akan habis dan memerlukan waktu yang sangat lama untuk mendapatkannya lagi. Biasanya sumber daya alam yang tidak dapat diperbarui berasal dari bahan galian (emas, perak, timah, besi, nikel dan lain-lain) dan barang tambang (minyak bumi dan batu bara). Aturan atau regulasi tersebut dikenal dengan istilah hukum pertambangan. Hukum pertambangan merupakan hukum yang memuat aturan tentang pengelolaan, hubungan negara dengan negara lain dan negara dengan pihak pengelolaan dalam urusan pengelolaan dan pemanfaatan bahan tambang dan bahan galian.

Pada Undang-undang Nomor 4 Tahun 2009 tentang pertambangan dalam pasal 1 huruf (1 dan 15) menjelaskan mengenai pengertian pertambangan yaitu

\footnotetext{
${ }^{5}$ Romli Atmasasmita, Teori dan Kapita Selekta Kriminologi, Bandung, 2005, hal 58

${ }^{6}$ Barda Nawawi Arief, Bunga Rampai Kebijakan Hukum Pidana, Prenada Madia Group, Jakarta. 2010, hal. 29-30

${ }^{7}$ Teguh Prasetyo, Kriminalisasi Dalam Hukum Pidana, Bursa Media, Bandung,2010, hal.19-20
} 
Muhammad Badri dan Eka Pitri, Penegakan Hukum terhadap Pelaku Tindak Pidana Pertambangan Minyak Tanpa Izin (Illegal Drilling) di Wilayah Hukum Kabupaten Batanghari

\section{Pasal 1 huruf 1}

Pertambangan adalah sebagian atau seluruh tahapan kegiatan dalam rangka penelitian, pengelolaan dan pengusahaan mineral atau batu bara yang meliputi penyelidikan umum, eksplorasi, studi kelayakan, konstruksi, penambangan, pengolahan dan pemurnian, pengangkutan dan penjualan, serta kegiatan pascatambang.

\section{Pasal 1 huruf 15}

Eksplorasi adalah tahapan kegiatan usaha pertambangan untuk memperoleh informasi secara terperinci dan teliti tentang lokasi, bentuk, dimensi, sebaran, kualitas dan sumber daya terukur dari bahan galian, serta informasi mengenai lingkungan sosial dan lingkungan hidup.

Adapun sanksi yang terkait dengan pertambangan minyak tanpa izin (illegal drilling) pada undang-undang pertambangan yaitu pada pasal 158 yang berbunyi :

Setiap orang yang melakukan usaha penambangan tanpa IUP, IPR atau IUPK sebagaimana dimaksud dalam Pasal 37, Pasal 40 ayat (3), Pasal 48, Pasal 67 ayat (1), Pasal 74 ayat (1) atau ayat (5) dipidana dengan pidana penjara paling lama 10 (sepuluh) tahun dan denda paling banyak Rp10.000.000.000,00 (sepuluh miliar rupiah).

Dalam Undang-Undang Nomor. 22 Tahun 2001 Tentang Minyak dan Gas Bumi sudah jelas telah melarang pertambangan minyak tanpa izin karena minyak dan gas bumi merupakan kekayaan alam yang tidak terbarukan dan merupakan sumber daya alam yang sangat strategis dan pengelolaannya menyangkut hajat banyak orang sehingga dalam pengelolaannya harus dapat dimaksimalkan sebesar mungkin untuk hajat banyak orang. Selain itu sumber daya minyak bumi dan gas menjadi komoditas vital dalam memberikan dan meningkatkan ekonomi nasional guna pertumbuhan ekonomi nasional.

Dalam undang-undang Nomor. 22 Tahun 2001 Tentang Minyak dan Gas Bumi, juga memberikan sanksi bagi pertambangan minyak tanpa izin dimana dalam pasal 52 disebutkan bahwa para pelaku pertambangan minyak tanpa izin (ilegal drilling) dapat dipidana dengan pidana penjara paling lama 6 tahun penjara dan denda paling tinggi Rp60 Miliar, kemudian dalam pasal 53 huruf a menjelaskan bahwa pelaku dapat diancam yaitu : Pengolahan sebagaimana dimaksud dalam Pasal 23 tanpa Izin Usaha Pengolahan dipidana dengan pidana penjara paling lama 5 (lima) tahun dan denda paling tinggi Rp50.000.000.000,00 (lima puluh miliar rupiah)

Pemberantas tindak pidana pertambangan minyak tanpa izin (illegal drilling) jika mengharapkan pemberantasannya oleh pemerintah tidak akan dapat diselesaikan semaksimal mungkin tanpa adanya campur tangan dan partisipasi masyarakat. Diperlukan usaha nyata dari seluruh pihak dalam memberantas tindak pidana illegal drilling. Dampak dari illegal drilling tersebut dapat menimbulkan penyakit kanker, pernafasan dan paru-paru, dan juga pencemaran lingkungan baik itu air, tanah ataupun udara. Hal ini bisa saja terjadi dikarenakan minyak bumi mentah merupakan senyawa hidrokarbon yang memiliki tempat yang mempunyai tekanan tertentu, sehingga ketika berada diluar tekanan tersebut misalnya diluar tanah dengan tanpa pengelolaan yang baik akan menimbulkan dampak yang disebutkan tadi. Tanha dan air yang terkena tetesan minyak mentah akan menjadi hitam dan berminyak yang menandakan adanya proses pencemaran yang terjadi dan dapat menyebabkan kerusakan ekosistem di lingkungan tanah dan air tersebut.

Pertambangan minyak tanpa izin (illegal drilling) di Kecamatan Bajubang, Kabupaten Batanghari, Jambi hingga saat ini masih berlangsung bahkan semakin marak baik itu masyarakat, mengingat hasil yang didapat dari pertambangan minyak tanpa izin (ilegal drilling) sangat menjanjikan dari segi ekonomi adapun alasan masyarakat melakukan kejahatan pertambangan minyak tanpa izin (ilegal drilling), karena dari hasil dari pertambanga minyak tanpa izin (ilegal drilling) hasil tersebut dapat menghasilkan dalam satu hari bisa mendapatkan hasil 1-3 juta per-hari untuk pengolahan penyulingan melalui kuali, kalau untuk pengeboran sumur penghasilan dapat 5-10 juta per-hari, walaupun pertambangan minyak secara tanpa izin (ilegal), selain merugikan keuangan negara, juga menyebabkan kerusakan lingkungan, membahayakan kesehatan bahkan membahayakan jiwa tidak hanya penambang namun juga masyarakat sekitar sumur, tersebut di karena dari hasil per-hari tersebut diatas. ${ }^{8}$

Mengingat Kabupaten Batanghari merupakan kabupaten yang masih dalam perkembangan dalam segala bidang termasuk dalam perkembangan hukum yang berlaku. Perkembangan hukum yang terjadi tentunya berbarengan dengan perkembangan permasalahan hukum yang terjadi di kabupaten Batanghari. Salah satu permasalahan hukum yang terjadi di Kabupaten Batangharu yaitu Salah satunya permasalahan tentang pengeboran minyak tanpa izin (ilegal drilling) di Kabupaten Batanghari yang memprihatinkan.

Kasus pertambangan minyak tanpa izin (illegal drilling) yang terjadi di Kabupaten Batanghari dari data internet terbaru dari tahun 2017 sampai 2019 berjumlah 29 kasus pada tahun 2017 berjumlah 9 kasus, pada tahun 2018 berjumlah 11 kasus. dan pada tahun 2019 berjumlah 9 kasus.

${ }^{8}$ Hasil Wawancara Dengan Pelaku Penambang Minyak Tanpa Izin Di Desa Bathin Kampung 6 Kecamatan Bajubang Kabupaten Batanghari Pada Tanggal 18 Desember 2019 


\section{METODE}

Di dalam penelitian diperlukan suatu metode penelitian agar suatu penelitian dapat dengan jelas arah dan tujuan yang akan diteliti, sehingga dapat menemukan hasil yang akan diteliti serta yang ingin dicapai dalam penelitian ini, adapun metode penelitian ini yaitu :Penegakan Hukum Terhadap Pelaku Tindak Pidana Pertambangan Minyak Tanpa Izin (Illegal Drilling) Di Wilayah Hukum Kabupaten Batanghari

\section{Metode Pendekatan}

Pendekatan dipakai pada pengkajian ini merupakan metodologi yuridis empiris yang merupakan metode penelitian hukum dengan melakukan penelitian langsung dilapangan dengan pengamatan perilaku manusia secara langsung melalui fakta-fakta empiris dilapangan. ${ }^{9}$ Penelitian ini adalah penelitian deskriptif analitis. Suatu pengkajian deskriptif guna memberikan memberikan bahansebagai untuk diteliti seperti orang, kondisi atau segala-segala lainnya. ${ }^{10}$ Dalam penelitian ini akan digambarkan tentang Penegakan Hukum Terhadap Pelaku Tindak Pidana Pertambangan Minyak Tanpa Izin (Illegal Drilling) Di Wilayah Hukum Kabupaten Batanghari

\section{Rancangan kegiatan}

Penelitian ini merupakan penelitian deskriptif analitis sehingga rancangan kegiatan yang dilakukan terkait dengan Penegakan Hukum Terhadap Pelaku Tindak Pidana Pertambangan Minyak Tanpa Izin (Illegal Drilling) Di Wilayah Hukum Kabupaten Batanghari yaitu dengan melakukan komunikasi atau wawancara dengan narasumber untuk mendapatkan data yang jelas dan lebih akurat serta informasi yang diperlukan. Oleh karenanya, data dan informasi tersebut didapatkan dengan melakukan wawancara bersama Kanit Sat-Reskrim Tipiter Polres Batanghari yang berhubungan dengan Penegakan Hukum Terhadap Pelaku Tindak Pidana Pertambangan Minyak Tanpa Izin (Illegal Drilling) Di Wilayah Hukum Kabupaten Batanghari

\section{Ruang lingkup atau objek}

Ruang lingkup atau objek dalam penelitian ini diperlukan guna membatasi fokus penelitian yang akan dikaji sehingga tidak melebar dan meluas dari fokus awal penelitian. Ruang lingkup juga memberikan kemudahan kepada peneliti terhadap penelitian yang dilakukan dan pembaca untuk memahami penelitian ini. Adapun ruang lingkup di dalam penelitian ini adalah Penegakan Hukum Terhadap Pelaku Tindak Pidana Pertambangan Minyak Tanpa Izin (Illegal Drilling) Di Wilayah Hukum Kabupaten Batanghari

\section{Bahan dan alat utama}

Dalam penelitian ini bahan dan alat utama yang penulis lakukan yaitu dengan melakukan wawancara mengingat bahwa penelitian berbentuk empiris maka penulis melakukan wawancara yang merupakan suatu metode pengumpulan data dengan melakukan komunikasi dua arah guna mendapatkan informasi yang dibutuhkan. Wawancara dalam penelitian ini yaitu dengan menanyakan langsung secara lisan dan tertulis dengan Kanit Sat-Reskrim Tipiter Polres Batanghari

\section{Teknik pengumpulan data}

Teknik pengumpulan data dalam penelitian ini disesuaikan dengan jenis dan pendekatan penelitian yang digunakan, maka pengumpulan data langsung dari lapangan dan dilakukan dengan teknik wawancara. Wawamcara tersebut dilakukan dengan Kanit Sat-Reskrim Tipiter Polres Batanghari

\section{Teknik analisis}

Data dan informasi yang diperlukan telah terkumpul, maka langkah selanjutnya yaitu dilakukan analisis data secara kualitatif. Keterangan dan jawaban dari responden tersebut dipilah dan ditarik kesimpulan secara deskriptif mengenai Penegakan Hukum Terhadap Pelaku Tindak Pidana Pertambangan Minyak Tanpa Izin (Illegal Drilling) Di Wilayah Hukum Kabupaten Batanghari

\section{HASIL DAN PEMBAHASAN}

\section{Penegakan Hukum Terhadap Tindak Pidana Pertambangan Minyak Tanpa Izin Di Wilayah Hukum Kabupaten Batanghari}

Penegakan hukum juga merupakan suatu proses untuk dilakukannya upaya tegaknya norma-norma hukum secara nyata sebagai tuntunan perilaku tengah-tengah masyarakat sehingga timbullah suatu hukum dalam kehidupan bermasyarakat dan bernegara. Penegakan hukum merupakan tugas dari aparat penegak hukum. aparat penegak hukum

\footnotetext{
${ }^{9}$ Rony Hamitijo Soemitro, Metodologi Penelitian Hukum dan Jurimetri, Ghalia Indonesia, Semarang 1998, hal, 97

${ }^{10}$ Soerjono Soekanto, Pengantar Penelitian Hukum, UI Press, Jakarta, 1981, hal. 10.
} 
merupakan lembaga atau institusi penegak hukum seperti polisi, jaksa, hakim, penasehat hukum dan petugas sipir pemasyarakatan, mengingat bahwa kelima lembaga tersebut merupakan aparat penegak hukum secara langsung berperan terhadap proses tegaknya aturan hukum.

Tegaknya suatu aturan hukum, sangat dibutuhkan aparat penegak hukum yang tegas dalam melakukan penegakan hukum dan seharusnya para aparat penegak hukum diperbolehkan untuk menggunakan daya paksa di karenakan untuk menjalankan amanat undang-undang dan dengan hal tersebut maka wibawah hukum di tengah-tengah masyarakat akan menjadi baik. Adapun norma hukum yang akan ditegakkan meliputiartidari hukum formil dan hukum materiil yaitu kalauhukum formil berkaitan dengan peraturan perundang-undangan yang tertulis, sedangkan hukum materiil mencakup pula pengertian nilai keadilan yang berada di tengah-tengah masyarakat.

Penegakan hukum merupakan implementasi dari kebijakan kriminal (criminal policy) dengan menggunakan sarana penal (penal policy), yang dilakukan melalui cara sistem peradilan pidana (criminal justice system), dan apabila sistem peradilan tersebut tidak berjalan semana mestinya maka hal tersebut menghambat berjalannya proses penegakan hukum, termasuk dalam penegakan hukum terhadap pertambangan minyak tanpa izin (illegal drilling), yang terjadi di Kabupaten Batanghari.

Proses penegakan hukum pada kasus pertambangan minyak tanpa izin (illegal drilling) di Kabupaten Batanghari, diawali dengan penyelidikan oleh penyidik. Penyidik merupakan Pejabat Polisi Negara Republik Indonesia atau Pejabat Pegawai Negeri Sipil (PPNS) tertentu yang diberi wewenang khusus oleh undang-undang untuk melakukan penyidikan dan diatur pada KUHAP Pasal 1.

Kanit Sat-Reskrim Tipidter Polres Batanghari terkait dengan tindak pidana pertambangan minyak tanpa izin (illegal drilling) mengatakan: kami dari pihak Polres Batanghari melakukan tindakan represif atau tindakan penindakan ketika atau setelah tindak pidana itu terjadi. Hal ini kami lakukan sebagai bentuk penegakan hukum dan membuat jera kepada pelaku dan masyarakat lainnya. Tindakan represif yang kami lakukan yaitu melakukan penyelidikan, penyidikan dan penangkapan kepada pelaku.

Kanit Sat-Reskrim Tipidter Polres Batanghari melakukan fungsi dan tugas dari kepolisian Republik Indonesia dengan menjalankan ketentuan hukum yang berlaku dalam penegakan hukum terhadap tindak pidana pertambangan minyak tanpa izin. Kami melakukan tindakan hukum sesuai dengan prosedur berdasarkan laporan yang diterima, yaitu dimulai dengan penyidikan, penyidik menyerahkan berkas perkara yang sudah lengkap atau P-21 beserta barang bukti kepada kejaksaan untuk diproses lebih lanjut.

Kanit Sat-Reskrim Tipidter Polres Batanghari dalam hal penegakan hukum terhadap tindak pidana pertambangan minyak tanpa izin (illegal drilling) yaitu melakukan Penahanan terhadap tersangka, penahanan ini dilakukan guna menghidari pelaku melarikan diri, atau pelaku mencoba menghilangkan barang bukti ataupun menghindari pelaku untuk melakukan tindak pidana lagi.

Berdasarkan penjelasan diatas maka di dalam penegakan hukum telah dilaksanakan oleh pihak Kepolisian Resort Batanghari dilihat dari penjelasan diatas yang mana kasus-kasus tersebut telah dilimpahkan ke kejaksaan untuk dilanjutkan ke pengadilan. Kemudian dari pada itu, tindakan penegakan hukum yang dilakukan juga bertujuan untuk memberikan pengetahuan keada masyarakat sehingga masyarakat sadar dan menghargai hukum yang berlaku dan nantinya masyarakat akan patuh terhadap hukum yang berlaku serta menumbuh dan menanamkan hukum dalam diri masyarakat.

\section{Kendala yang dihadapi oleh aparat penegak hukum dalam menangani Tindak Pidana Pertambangan Minyak Tanpa Izin Di Wilayah Hukum Kabupaten Batanghari}

Setiap menjalankan suatu pekerjaan maka akan dihadapi suatu hambatan atau kendala termasuk para penegak hukum ketika aparat penegak hukum dalam melakukan tugasnya khusunya dalam penegakan hukum terhadap pelaku tindak pidana pertambangan minyak tanpa izin (illegal drilling) di Kabupaten Batanghari.

Kemudian kendala yang dihadapi penegak hukum dalam mengatasi tindak pidana pertambagangan minyak tanpa izin di Kabupaten Batanghari yaitu kendala dari masyarakatnya, karena tingkat kesadaran dan partisipasi yang masih rendah. Tingkat kesadaran dan partisipasi yang rendah dari masyarakat seakan-akan masyarakat itu terkesan tidak peduli dengan kejahatan yang terjadi di lingkungannya sendiri khususnya tindak pidana pertambagangan minyak tanpa izin di Kabupaten Batanghari. dari faktor budaya kebiasaan masyarakat di Kabupaten Batanghari apabila ada suatu pelanggaran hukum atau suatu tindak pidana yang dianggap bahwa tindak pidana tersebut tidak terlalu merugikan atau dengan kata lain suatu tindak pidana pertambagangan minyak tanpa izin masyarakat tersebut dengan untuk melapor ke pihak penegak hukum atau pihak kepolisian sehingga perbuatan tindak pidana pertambagangan minyak tanpa izin semakin hari semakin meningkat.

Kanit Sat-Reskrim Tipiter Polres Batanghari menjelaskan kendala lain yang dihad api oleh pihaknya dalam menegakkan hukum pada pertambangan minyak tanpa izin (illegal drilling) yaitu seringkali mendapatkan kendala seperti pada saat datang ke lokasi aktivitas para penambang tidak melakukan aktivitasnya sehingga lokasi pertambangan tersebut tidak ditemukan pelakunya atau pekerja tambang tanpa izin tersebut 
Dari hal tersebut di atas bahwa tidak adanya aktivitas di lokasi menurut Iswan Hadi Kanit Sat-Reskrim Tipiter Polres Batanghari menjelaskan bahwa : pihak Polres Batanghari merasa ada kebocoran informasi atau memberikan informasi dari oknum yang tidak bertanggung jawab kepada pelaku penambangan minyak tanpa izin di lokasi, sehingga pada saat mendatangkan ke lokasi pertambangan tidak ditemui aktivitas pertambangan minyak

Kanit Sat-Reskrim Tipiter Polres Batanghari menambahkan terhadap kendala penegakan hukum terhadap pertambangan minyak tanpa izin (illegal drilling) yaitu : Kurangnya informasi dari masyarakat karena masyarakat masih belum aktif dalam memberikan informasi sehingga kendala tersebut sangat dirasakan oleh para penegak hukum karena untuk melakukan penegakan hukum kepada pelaku pertambangan minyak tanpa izin diperlukan informasi dari masyarakat

Kanit Sat-Reskrim Tipiter Polres Batanghari menjelaskan terhadap kendala penegakan hukum terhadap pertambangan minyak tanpa izin (illegal drilling) yaitu :Kurang kesadaran masyarakat dalam mengatasi permasalah tindak pidana pertambangan minyak tanpa izin (illegal drilling) sehingga kami selaku penegak hukum tidak dapat berbuat banyak akibat tidak adanya dukungan masyarakat dalam menangani tindak pidana pertambangan minyak tanpa izin (illegal drilling) sehingga para penegak hukum seperti pihak kepolisian tidak dapat melakukan penegakan hukum secara maksimal

Dari beberapa penjelasan di atas bahwa kendala dalam melakukan penegakan hukum terhadap penambangan minyak tanpa izin (illegal drilling) oleh para penegak hukum seperti polisi yaitu ; setiap melakukan penegakan hukum maka akan timbul Kendala-kendala seperti Polres Batanghari masih kurangnya informasi dari masyarakat karena di dalam melakukan penegakan hukum yang dilakukan oleh kepolisian di perlunya dukungan dari masyarakat, apabila tidak adanya dukungan dari masyarakat maka penegakan hukum yang dilakukan kepolisian tidak akan teleksana dengan baik.

\section{Upaya apa yang dilakukan oleh para penegak hukum mengatasi kendala terhadap Tindak Pidana Pertambangan Minyak Tanpa Izindi Wilayah Hukum Kabupaten Batanghari}

Terhadap tindak pidana pertambangan minyak tanpa izin dan dalam pelaksanaannya di lapangan ditemui beberapa kendala seperti tidak adanya dukungan masyarakat untuk menjalankan amanat undang-undang, kemudian masih sulit untuk menemukan pelaku, Sulit untuk menemukan barang bukti barang hasil dari yang di tambang, selain itu juga kurangnya informasi yang didapat dari masyarakat dan juga kurang tanggapnya masyarakat terhadap tindak pidana pertambangan minyak tanpa izin dua dan banyaknya masyarakat tidak mengetahui tentang hukum sehingga kesadaran hukum di dalam masyarakat sangat kurang.

Agar upaya Kanit Sat-reskrim Tipiter Kepolisian Resor Batanghari selaku aparat penegak hukum dapat berjalan sebagaimana mestinya maka perlu adanya langkah-langkah terhadap masalah yang dihadapi. Beberapa di antara permasalahan tersebut diatas setidaknya dapat dicarikan solusi dalam mengatasi nya guna menegakkan hukum pada tindak pidana pertambangan minyak tanpa izin.

Kanit Kanit Sat-reskrim Tipiter Kepolisian Resor Batanghari menjelaskan bahwa : Upaya yang dilakukan oleh Polres Batanghari yaitu melakukan kerjasama dengan informan. Informan di sini adalah masyarakat, yaitu masyarakat kita berdayakan dan memaksimalkan perannya, ketika adanya aktivitas pertambangan minyak tanpa izin maka masyarakat sebagai informan untuk segera melaporkan kejadian tersebut ke Polres Batanghari.

Kanit Kanit Sat-reskrim Tipiter Kepolisian Resor Batanghari mengatakan bahwa selain dengan memberdayakan masyarakat sebagai informan, kami dari aparat penegak hukum juga melakukan tindakan pencegahan melalui himbauan dan penyuluhan kepada masyarakat. Himbauan dan penyuluhan tersebut kami lakukan ketika kami melakukan patroli. Adapun himbauan yang kami lakukan yaitu tindakan penambangan ini haruslah mendapatkan izin dan proses penedotan minyak tersebut haruslah sesuai dengan standar dari pertamina sehingga meminimalisir resiko terjadinya hal-hal yang tidak diinginkan. Selain itu kami juga melakukan penangkapan kepada para pelaku penambangan minyak tanpa iin untuk dilakukan proses hukum kepada pelaku.

Dari penjelasan para penegak hukum di atas maka di dalam penegakan terhadap tindak pidana pertambangan minyak tanpa izin (illegal drilling) melakukan kerjasama dengan aparat penegak hukum lainnya kemudian melakukan kerjasama antara penegak hukum dan pemerintah Kabupaten Batanghari.

\section{SIMPULAN}

1. Penegakan hukum yang dilakukan oleh Polres Batanghari terhadap tindak pidana penambangan minyak tanpa izin (illegal drilling) yang terjadi di wilayah hukum Kabupaten Batanghari yaitu dengan melakukan penegakan dan penindakan meliputi penyelidikan, penyidikan dan penahanan. Selain itu juga kami melakukan tindakan pencegahan dengan himbauan dan penyuluhan.

2. Kendala yang ditemui yaitu kurangnya kesadaran dan partisipasi dari masyarakat, serta kurangnya informasi yang didapatkan dari masyarakat. 
Muhammad Badri dan Eka Pitri, Penegakan Hukum terhadap Pelaku Tindak Pidana Pertambangan Minyak Tanpa Izin (Illegal Drilling) di Wilayah Hukum Kabupaten Batanghari

3. Upaya yang dilakukan terhadap kendala yang ditemui yaitu memberdayakan dan memaksimalkan masyarakat untuk menjadi informan, bekerja sama baik antar penegak hukum maupun aparat penegak hukum dengan emerintah kabupaten batanghari.

\section{DAFTAR PUSTAKA}

Satjipto Rahardjo, Sisi-sisi Lain dari Hukum di Indonesia, Penerbit Kompas, Jakarta, 2006

Muladi, Lembaga Pidana Bersyarat, cetakan ketiga, Alumni, Bandung, 2005

Romli Atmasasmita, Teori dan Kapita Selekta Kriminologi, Bandung, 2005

Barda Nawawi Arief, Bunga Rampai Kebijakan Hukum Pidana, Prenada Madia Group, Jakarta. 2010

Teguh Prasetyo, Kriminalisasi Dalam Hukum Pidana, Bursa Media, Bandung,2010

Rony Hamitijo Soemitro, Metodologi Penelitian Hukum dan Jurimetri, Ghalia Indonesia, Semarang 1998

Soerjono Soekanto, Pengantar Penelitian Hukum, UI Press, Jakarta, 1981 